\title{
Al-La-Ni (Aluminum-Lanthanum-Nickel)
}

\section{Raghavan}

Recently, [2001God] determined a liquidus surface for Alrich alloys of this system and a vertical section at 90 at.\% Al.

\section{Binary Systems}

The Al-La phase diagram [Massalski2] depicts seven intermediate phases: $\alpha \mathrm{La}_{3} \mathrm{Al}_{11}$ (orthorhombic), $\beta \mathrm{La}_{3} \mathrm{Al}_{11}$ $\left(D 1_{3}\right.$, Al-deficient $\mathrm{Al}_{4} \mathrm{Ba}$-type tetragonal), $\mathrm{LaAl}_{3}\left(D 0_{19}\right.$, $\mathrm{Ni}_{3}$ Sn-type hexagonal), $\mathrm{LaAl}_{x}\left(C 32, \mathrm{AlB}_{2}\right.$-type hexagonal), $\mathrm{LaAl}_{2}\left(C 15, \mathrm{MgCu}_{2}\right.$-type cubic), LaAl (CeAl-type orthorhombic), and $\mathrm{La}_{3} \mathrm{Al}\left(\mathrm{DO}_{19}, \mathrm{Ni}_{3} \mathrm{Sn}\right.$-type hexagonal). The Al$\mathrm{Ni}$ phase diagram [19930ka] shows five intermediate phases: $\mathrm{NiAl}_{3}\left(D 0_{11}, \mathrm{Fe}_{3} \mathrm{C}\right.$-type orthorhombic), $\mathrm{Ni}_{2} \mathrm{Al}_{3}$ (D5 $5_{13}$-type hexagonal), $\mathrm{NiAl}$ (CsCl-type cubic), $\mathrm{Ni}_{5} \mathrm{Al}_{3}$ ( $\mathrm{Ga}_{3} \mathrm{Pt}_{5}$-type orthorhombic), and $\mathrm{Ni}_{3} \mathrm{Al}\left(\mathrm{Ll}_{2}, \mathrm{AuCu}_{3}\right.$-type cubic; also denoted $\gamma^{\prime}$ ). The La-Ni phase diagram [Massalski2, 2002Oka] shows a number of intermediate phases: $\mathrm{LaNi}_{5}\left(D 2_{d}, \mathrm{CaCu}_{5}\right.$-type hexagonal $), \mathrm{La}_{2} \mathrm{Ni}_{7}\left(\mathrm{Ce}_{2} \mathrm{Ni}_{7}\right.$-type hexagonal), $\mathrm{LaNi}_{3}\left(\mathrm{PuNi}_{3}\right.$-type rhombohedral), $\mathrm{LaNi}_{2}(C 15$, $\mathrm{MgCu}_{2}$-type cubic), $\mathrm{La}_{2} \mathrm{Ni}_{3}$ (orthorhombic), LaNi ( $B_{f}, \mathrm{CrB}$ type orthorhombic), $\mathrm{La}_{7} \mathrm{Ni}_{3}\left(D 10_{2}, \mathrm{Fe}_{3} \mathrm{Th}_{7}\right.$-type hexagonal), and $\mathrm{La}_{3} \mathrm{Ni}\left(D 0_{11}, \mathrm{Fe}_{3} \mathrm{C}\right.$-type orthorhombic).

\section{Ternary Phases}

Three ternary compounds of this system are listed in the compilation by [1995Vil]. AlLaNi and $\mathrm{Al}_{3} \mathrm{LaNi}_{2}$ are orthorhombic. $\mathrm{Al}_{5} \mathrm{LaNi}_{2}$ has the $\mathrm{Al}_{5} \mathrm{Ni}_{2}$ Pr-type orthorhombic structure. Two other phases $\mathrm{AlLaNi}_{4}$ and $\mathrm{Al}_{25} \mathrm{La}_{17} \mathrm{Ni}_{58}$

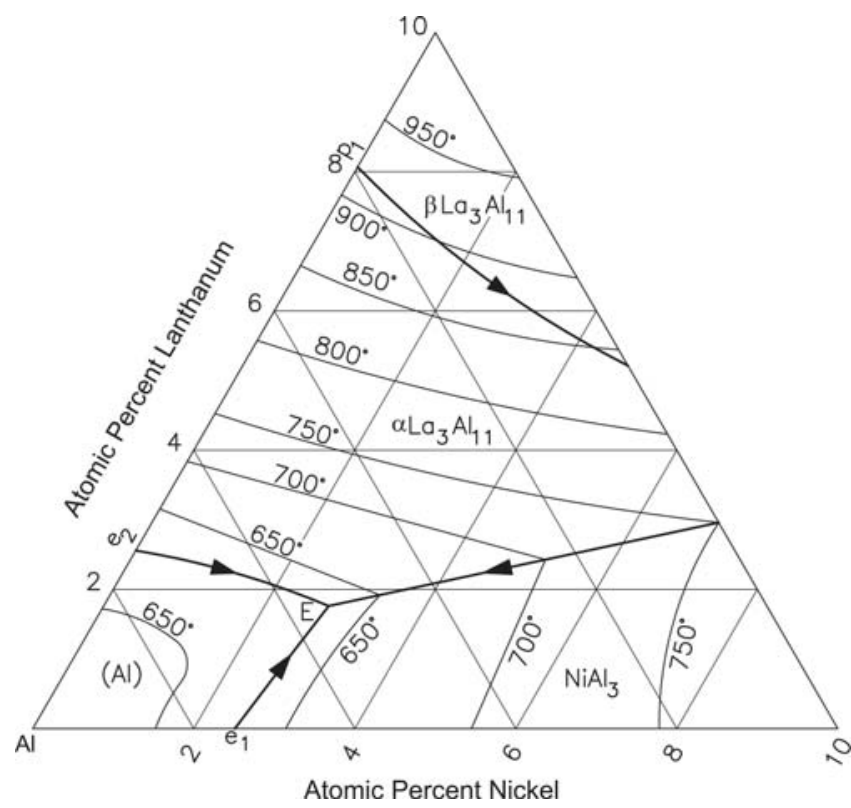

Fig. 1 Al-La-Ni liquidus projection for Al-rich alloys [2001God]

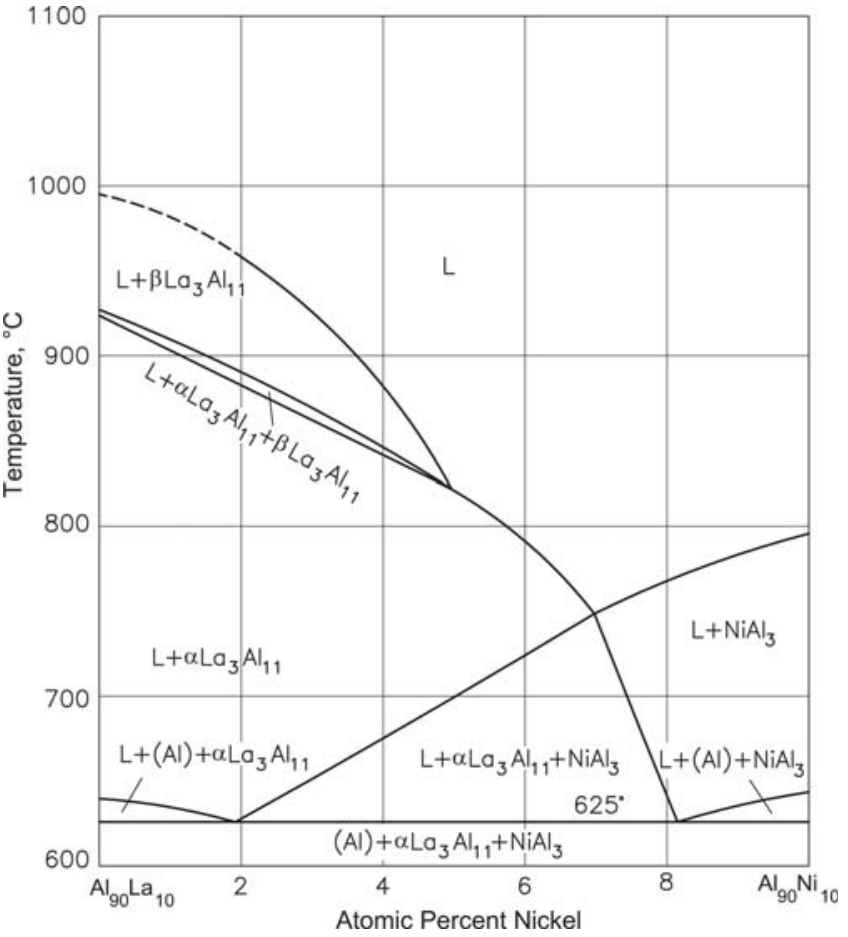

Fig. 2 Al-La-Ni vertical section at 90 at.\% Al [2001God]

[1995Vil] lie on the extension of the binary phase $\mathrm{LaNi}_{5}$ into the ternary region at constant La content.

\section{Ternary Phase Equilibria}

Starting with high-purity metals, [2001God] melted Alrich alloy compositions in an arc furnace under Ar atmosphere. The phase equilibria were studied using differential thermal analysis, x-ray diffraction, and optical and scanning electron metallography. The liquidus surface determined by [2001God] is redrawn in Fig. 1. The solidification of the Al-rich alloys is through the ternary eutectic reaction $\mathrm{E}: \mathrm{L} \leftrightarrow(\mathrm{Al})+\mathrm{NiAl}_{3}+\alpha \mathrm{La}_{3} \mathrm{Al}_{11}$ at $625^{\circ} \mathrm{C}$. A vertical section constructed by $[2001 \mathrm{God}]$ along the $\mathrm{Al}_{90} \mathrm{La}_{10}-\mathrm{Al}_{90} \mathrm{Ni}_{10}$ join is shown in Fig. 2.

\section{References}

1993Oka: H. Okamoto, Al-Ni (Aluminum-Nickel), J. Phase Equilibria, 1993, 14(2), p 257-259

1995Vil: P. Villars, A. Prince, and H. Okamoto, Al-La-Ni, Handbook of Ternary Alloy Phase Diagrams, Vol 4, ASM International, 1995, p 3836-3837

2001God: T. Godecke, W. Sun, R. Luck, and K. Lu, Metastable Al-Nd-Ni and Stable Al-La-Ni Phase Equilibria, Z. Metallkd., 2001, 92(7), p 717-722

2002Oka: H. Okamoto, La-Ni (Lanthanum-Nickel), J. Phase Equilibria, 2002, 23(3), p 287-288 